This item was submitted to Loughborough's Research Repository by the author.

Items in Figshare are protected by copyright, with all rights reserved, unless otherwise indicated.

\title{
As it was, is, or will be played: title-pages and the theatre industry to 1610
}

PLEASE CITE THE PUBLISHED VERSION

PUBLISHER

Palgrave Macmillan

LICENCE

CC BY-NC-ND 4.0

\section{REPOSITORY RECORD}

Egan, Gabriel. 2019. "As It Was, Is, or Will Be Played: Title-pages and the Theatre Industry to 1610". figshare. https://hdl.handle.net/2134/3703. 
This item was submitted to Loughborough's Institutional Repository by the author and is made available under the following Creative Commons Licence conditions.

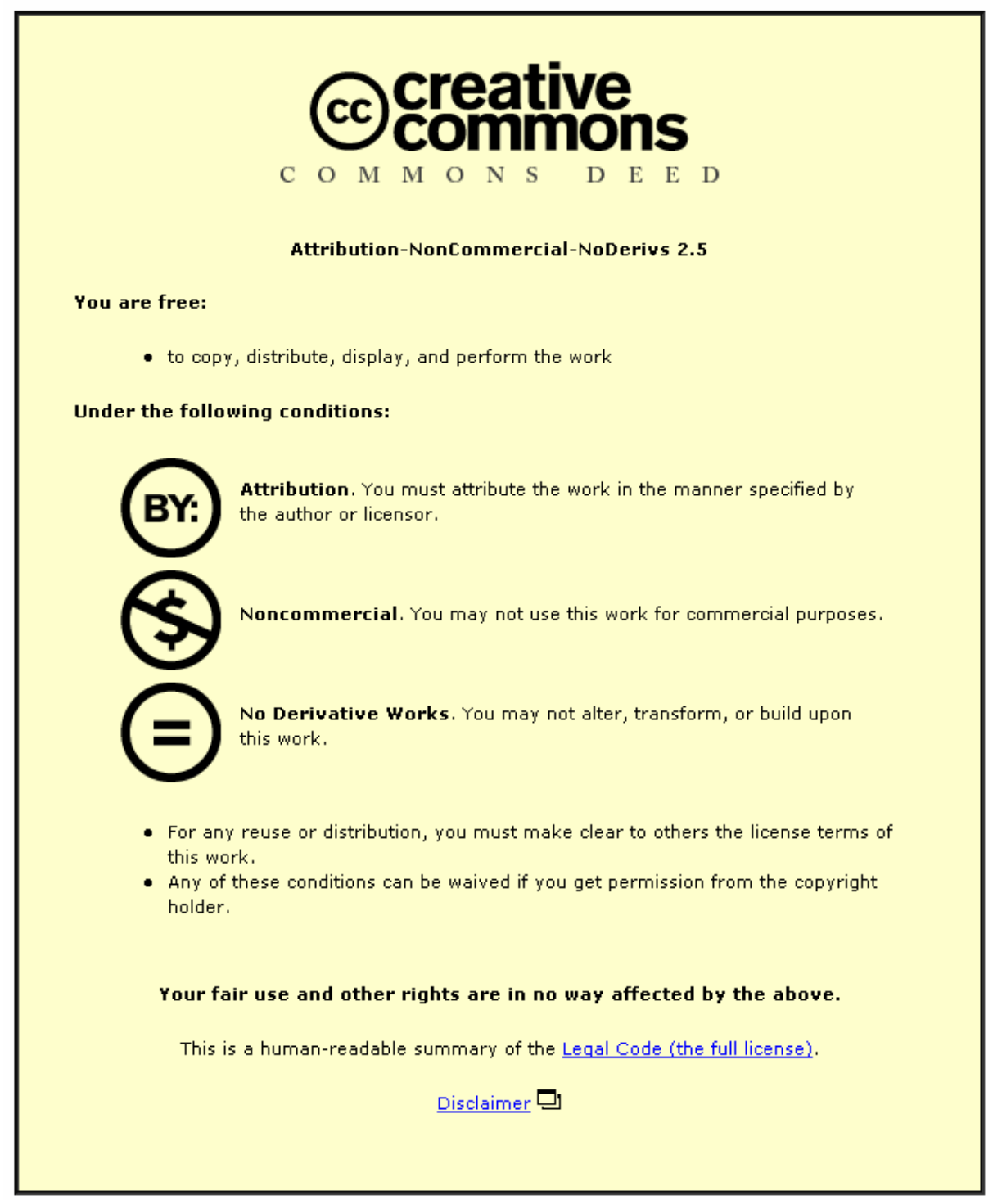

For the full text of this licence, please go to: http://creativecommons.org/licenses/by-nc-nd/2.5/ 
Egan, Gabriel. 2006b. "'As it Was, Is, or Will be Played': Title-pages and the Theatre Industry to 1610." From Stage to Print in Early Modern England. Edited by Peter Holland and Stephen Orgel. Redefining British Theatre History. London.

Palgrave Macmillan. pp. 92-110

\section{"'As it was, is, or will be played': Title-pages and the theatre industry to 1610" by Gabriel Egan}

Whereas modern actors usually start with a printed text of some form, we are used to the idea that early modern actors started with manuscripts and that printing followed performance. Confirming this, the title-pages of printed plays refer back to past performance with such phrases "As it hath beene publikely acted by the right Honourable the Lorde Chamberlaine his Seruants" (Shakespeare 1597, A1r) or "As it was acted by the Kings Maiesties seruants at the Globe" (Shakespeare 1609b, A1r) to take examples from two first printings of Shakespeare plays. These locutions promise the reader that the contents will be "as" the play was acted, that the text captures something of the pleasure of performance, although my second example, the phrasing on the title-page of the first printing of Troilus and Cressida, comes from a book that survives in two states ( $\mathrm{Qa}$ and $\mathrm{Qb})$. $\mathrm{Qb}$ has a reset title-page that removes the reference to performance but adds that the lovers' 'history' is "Famous" (Shakespeare 1609a, П1r). The necessity that this second state could not refer back to a performance--apparently because whoever printed it discovered that it had not been publicly performed--was made into virtue with an epistle that emphasizes the readerly benefits. At least, that is one way to read it. Alternatively, Gary Taylor's conjecture is that the epistle was written in 1603 when the play was surreptitiously obtained by a printer after the Inns of Court premiere. The printing was blocked, or not attempted, and the play went on to be performed at the Globe. When it came to be printed in 1609, the printers assumed that it had been played at the Globe and wrote the title-page to $\mathrm{Qa}$, but towards the end of the printing they found the epistle, believed it, and so they set a new title-page and added the epistle (Taylor 1982, 118-21).

Even if, as Taylor reckons, the epistle is several years earlier than the printing it precedes, its phrasing is nonetheless caught between apologizing for the nonperformance and making a virtue of it. Part of that virtue is its freshness (". . . you haue heere a new play, neuer stal'd with the Stage") and part is elitist access to something that "the vulger" have not enjoyed. However, the epistle also claims that reading is an alternative route to Shakespeare's 'wit' (his attribute the epistle repeatedly stresses) and one that will endure long after the originating performances:

And had I time I would comment vpon it . . . . It deserues such a labour, as well as the best Commedy in Terence or Plautus. And beleeue this, that when hee [that is, Shakespearel is gone, and his Commedies out of sale, you will scramble for them ... Take this for a warning, and at the perrill of your pleasures losse, and ludgements, refuse not, nor like this the lesse, for not being sullied, with the smoaky breath of the multitude; but thanke fortune for the scape it hath made amongst you. (Shakespeare 1609a, T2v)

Just as Terence and Plautus are gone and their works must be enjoyed from print, so necessarily Shakespeare will go the same way. Of course, actors can put on the plays of Terence and Plautus afresh, but only from the printed texts that exist, so there is a backwards and forwards tension in printed playtexts: they preserve what was performed (and can give again something of the pleasure of those performances), and they can originate fresh performances. 
Published the same year, 1609, the printed playtext of Pericles was indeed used to originate fresh performances, those of the company led by Richard and Christopher Simpson under the patronage of Richard Cholmley that played to Catholic audiences in Yorkshire, as described by C. J. Sisson (1942), G. W. Boddy (1976), and Peter Holland (2004). When tried for sedition these players insisted (falsely, it turned out) that they had not strayed from the printed texts, apparently thinking that this gave them a kind of surrogate licence from the Master of the Revels who had licensed the original manuscripts underlying the printing. One of the actors reported that at Candlemas 160910 they performed "Perocles prince of Tire", which was undoubtedly the work of Shakespeare and Wilkins, and "Kinge Lere" which might have been Shakespeare's (his quarto was the most recent) but equally might have been the old chronicle history of King Leir printed in 1605 (Anonymous 1605b). This essay will survey how play printings' title-pages characterized their relationship to performance, from the early printed books to the Simpsons' use of Pericles, noting how that relationship changed over the period.

\section{Title-pages, promotion, and the amateur-professional shift}

The capacity of a printed play to originate fresh performances was something that the title-pages and the preliminary matter of the very first printings in the early sixteenth century made much of. Often the printings helped would-be performers my listing the parts to be assigned, indicating those that could be taken by a single actor, and even how to cut the text for a desired performance duration:

... whiche interlude yf $y^{e}$ hole matter be playd wyl conteyne the space of an hour and a halfe | but yf ye lyst ye may leue out muche of the sad mater as the messengers $p<a r>t e$ | and some of the naturys parte and some of experyens $p<a r>t e ~ \&$ yet the matter wyl depend conuenytently | and than it wyll not be paste thre quarters of an hour of length (Rastell 1520?, A1r)

The earliest extant printed play in English is Henry Medwall's Fulgens and Lucrece (Medwall 1512-16) but the tradition really begins with the printing of Everyman that W. W. Greg thought, on the evidence that 4 known copies belong to 4 distinct editions, must have appeared in at least 10 early editions (Greg 1970a, 82). Then came Mundus \& Infans (Anonymous 1522) and then The Nature of the Four Elements just quoted. Thereafter in each decade from the 1520 s to the 1570 s somewhere between about a quarter to a half of all plays whose title-pages survive have on those title-pages a reference to potential future performance in the form of a list of parts or a statement of how easily a given number of actors may play it or a statement about the appropriate occasion for a performance such as "to be played in Maye games" (Anonymous 1560?, A1r). Specifically, the decade-by-decade proportions are $2 / 3,2 / 9,2 / 4,1 / 3,16 / 26$, and $6 / 19$, for the 1520 s to the 1570 s sequentially.

This trend abruptly ended with the first printed play of the next decade, The Conflict of Conscience, whose title-page featured a doubling chart "most conuenient for such as be disposed, either to shew this Comedie in priuate houses, or otherwise" (Woodes 1581, A1r). After The Conflict of Conscience, printed play title-pages acquired the now-familiar formulaic phrasing that described the contents being 'as it hath been played' (and variations thereon) rather than as material for new performances, and title-page references to (and aids for) future performance stop. For the next two-and-a-half decades no first edition printed play refers or gives aid to future performance on its title- 
page, although a reprint such as the 1582 edition of Richard Edwards's Damon and Pithias might inherit such a reference ("the proper vse of them that hereafter shal haue occasion to play it") from its predecessor (Edwards 1571, A1r; Edwards 1582, A1r). Over these two-and-a-half decades the printing of plays accelerated sharply: 15 plays were printed in the 1580s, 69 in the 1590s, and 124 in the first decade of the 1600s. (Occasionally appears a list of characters, as on the title-page of Marlowe's Dido Queen of Carthage (Marlowe \& Nashe 1594, A1r), but without guidance about how to distribute them amongst players; these appear to be readerly rather than performative aids.) In the great flourishing of play printing that forms the first third of the early modern dramatic canon (339 more plays were printed before the closure of 1642), title-pages almost always presented a book's contents as the opportunity to recover the pleasure of past performance rather than as a means to create new performances. The obvious explanation for this change happening in the early 1580s is the rise of the London professional theatre industry with the opening of permanent open-air amphitheatres in the suburbs: the Theatre in Shoreditch (1576) and its neighbour the Curtain (1577). From a marketing point of view, play printing became parasitic upon on the professional stage, whose pleasures the book was advertized as recapturing, rather than serving the (much smaller) demand for self-performable drama.

The same shift is detectable in what printed play books called their contents. The word 'play' itself was used on title-pages of sixteenth-century interludes by John Heywood--The Playe Called the Foure PP (Heywood 1544?b, A1r; Heywood 1560?, A1r; Heywood 1569, A1r), A Play of Loue (Heywood 1534, A1r), and The Play of the Wether (Heywood 1533, A1r; Heywood 1544?a, A1r; Heywood c.1560, A1r; Heywood c.1573, A1r)--and in their reprintings these reach almost to the Shakespearian period. Likewise an anonymous verse jest about Robin Hood was reprinted several times in the early decades of the sixteenth century and for a printing around 1560 "a newe playe" of about 200 lines was added (Anonymous 1560?, A1r). But just as references to potential future performances cease from 1581, so too does the use of the word 'play' on titlepages, and not until the 1609 printing of "THE LATE, and much admired Play, Called Pericles, Prince of Tyre" (Shakespeare \& Wilkins 1609, A1r) is a drama again called a 'play' on its title-page. And, by a suspiciously neat symmetry, searches of ChadwyckHealey's Literature Online database indicate that the word 'title-page' was not spoken in any drama before Pericles, so Simonides's "I place vpon the volume of your deedes, I As in a Title page, your worth in armes" (Shakespeare \& Wilkins 1609, D1r) is the first usage.

One has to be careful with such claims about phrasing, because some title-pages just plain lie. Thomas Nashe's Lenten Stuff promises on its title-page "a new Play neuer played before" (Nash 1599, A1r) in praise of red herring, but is itself a red herring because it is wholly a non-dramatic prose satire. Despite its being a hoax, that Nashe's work purports to be an unperformed play (as does the epistle to Troilus and Cressida) hints at a bucking of the trend concerning references to past performance. Another hoax, and another rare use of the word 'play', is the printed description of Richard Vennard's entertainment called England's Joy that promises an extraordinary spectacle including the representation of the monarch on the stage and the enactment of her success in struggles with Spain and Ireland (Vennard 1602). This is commonly called a playbill, and it certainly serves the playbill-like function of summarizing the performance: "THE PLOT OF THE PLAY, CALLED ENGLANDS JOY. To be Playd at the Swan this 6. 
of Nouember. 1602". In an article on playbills, Tiffany Stern pointed out that this is not a playbill but, as it says, a 'plot' of the kind

handed out (when they were) to an audience already at the theatre. They were not, that is to say, hung up around London, but were, rather, 'gifts' for an established audience: something like a modern 'programme'. Usually, though, 'plots' were the preserve of court ..... Indeed, Heironymo's gift of playbook and the 'Argument of that we show' to the King in Spanish Tragedy, is proof of the habit of giving plot-summaries out at court; the printed 'arguments' at the beginning of playbooks with literary pretensions probably reflect this habit. (Stern forthcoming, TBA)

Like a playbill, such a document necessarily looks forward to future (indeed, imminent) performance rather than reflecting on past performance. Stern found similarities between the phrasing of playbills (as she inferred from indirect evidence) and the phrasing of title-pages in such things as naming the play, the players, and the venue, and providing a summary of the action. The likeness extends to their usage, for both were pasted up around London as advertisements. Stern gave the reasons for believing that this happened to title-pages and cited R. B. McKerrow's observation that that is why title-pages tell readers where to buy the book, something that a customer would already know if he or she were reading the title-page in the bookshop itself (Stern forthcoming, TBA; McKerrow 1916, 232). However, Peter W. M. Blayney's assertion that the place of sale named in the imprint was the wholesaler from whom retailers could get the book wholesale (Blayney 1997, 390) throws doubt on this point, since that information would presumably not interest most potential buyers.

The printing of playbills was a monopoly from 1587 and the successive holders were John Charlewood from 1587 (Arber 1875, 477) to his death in 1593, James Roberts (by marrying Charlewood's widow) from 1594 (Arber 1875, 651-52) to when he sold his business to William Jaggard in 1606 or 1608 (Pollard \& Redgrave 1991, 145; McKerrow 1910, 229). In 1615 Roberts formally transferred his right to print playbills to Jaggard (Arber 1876, 575), who held the monopoly until his death in 1623, whereupon it passed to his son Isaac until his death in 1627 (Pollard \& Redgrave 1991, 90-91), and then via Isaac Jaggard's widow Dorothy to Thomas and Richard Cotes from 1627 (Arber 1877, 182 ) to the general closure of 1642. In 1582 a mass reassignment in the Stationers' Register (Arber 1875, 405-06) transferred from John (= Sampson) Awdely to Charlewood the right to print John Heywood's The Playe of the Foure PP, The Play of the Wether, and A Play of Loue--notable examples of the word 'play' in their previous printings--and although there is no sign that he did publish those, Charlewood had published the occasional Tudor interlude, as when in 1566 he published The Life and Repentaunce of Marie Magdelene that was advertized on its title-page as being "very delectable for those which shall heare or reade the same" and which came with a list of parts to how "Foure may easely play" it (Wager 1566, A1r). An undated list of books that James Roberts had a right to print (Herbert 1786, 1032) includes a number that had been Charlewood's and were transferred to him with the playbills monopoly on "ultimo maij [1594]" (Arber 1875, 651), but also shows that Roberts acquired the rights to Charlewood's former properties not mentioned in that transfer, namely The Playe of the Foure PP, The Play of the Wether, and A Play of Loue.

William Jaggard followed Roberts as the printer of playbills, getting the monopoly in 1606 (according to Katharine's F. Pantzer's index in the Short Title Catalogue) or in 
1608 (according to McKerrow's Dictionary of Printers), and when he printed George Wilkins's The Miseries of Inforst Mariage for George Vincent, Jaggard produced a titlepage claiming that the book represented the play "As it is now playd by his Maiesties Seruants" (Wilkins 1607, A1r). Such a reference to ongoing performance at the time of printing was new, and it is tempting to wonder if Jaggard's experience of printing playbills had something to do with it. Although he had not yet the monopoly, since December 1602 Jaggard had been printing playbills for certain playing companies upon payment of monthly fees to monopoly holder James Roberts (Jackson 1957, 1-2, 6); Jaggard had been seeking the right to print playbills as early as 23 April 1593 (Greg \& Boswell 1930, 46). Stern pointed out that a printed playbill would have provided ready copy for a play title-page, and wondered if the dramatist might not be expected to phrase such promotional material (Stern forthcoming, TBA), while Alan B. Farmer and Zachary Lesser noted that ". . . the ultimate decision lay with publishers, for they had all legal rights over the copy" (Farmer \& Lesser 2000, 104n9). A publisher who was producing playbills was likely to think of plays in the present and future tenses rather more strongly than one who was overtly presenting a post-performance text, and perhaps without consciously knowing it Jaggard started to phrase his title-pages to match this new conception of the relationship between book and performance. Whoever was responsible, the "As it is now play[e]d" phrasing appeared in another play publication of 1607: John Day, William Rowley, and George Wilkin's The Travailes of the Three English Brothers (Day, Rowley \& Wilkins 1607, A1r), printed by George Eld for John Wright.

Another publisher's output here intersects with the change in how title-pages characterize their relation to performance around 1605-10. Nathaniel Butter achieved freedom of the Stationers' Company by patronage on 20 February 1604 and as Sidney Lee's entry for him in the old Dictionary of National Biography observed, Butter's early career was founded on sensational reports of various kinds, including one (Anonymous 1605c) that became the sole source for the apocryphal Shakespeare play A Yorkshire Tragedy (Shakespeare 1608a), and from 1622 he "made journalism his chief business" (Smith, Stephen \& Lee 1937-38, 547). Butter's early work included anti-Catholic texts such as Thomas Bell's The Downefall of Poperie (Bell 1604) and a prose treatise of 1607 called The Jesuites Play at Lyons (S 1607). This book claims to report a performance, but the report is so strange that we must doubt its veracity. Dramatizing the Christian day of judgement, French Jesuits apparently took the roles of God, Christ, and the virgin Mary, and commanding all the fiends of hell they "seased on christian princes" including Henry 8, Edward 6, and Elizabeth 1 and sent them to hell (S 1607, $\mathrm{C} 4 \mathrm{v})$. The text retains a narrative frame: the reporter tells us what happened in the performance, and hence this is a prose story of the performance rather than the raw material for the performance itself. The narrator wants to get so much of the script into the report that the framing device is something of an intrusion, and at one point (S 1607, B3v) a 150-word speech is conveyed verbatim; one wonders if the narrator was tempted to dispense with it and simply give the alternating speeches with their speech prefixes.

One might say that any published playscript is a report of performance with the narrative frame dissolved and the words spoken presented as themselves. The antiCatholic author of The Jesuites Play at Lyons uses the narrative frame to comment on the performance, and without it the raw material would be open to fresh interpretative possibilities and might even permit it to originate fresh performances, to the peril of unwitting actors and audiences. The following year, 1608, Butter published George 
Wilkins's prose novella The Painfull Adventures of Pericles Prince of Tyre, which stands in a similar relation to the King's men's play about Pericles as the report stands to the putative performance at Lyons: the "true History of the Play of Pericles, as it was lately presented by the worthy and ancient Poet John Gower" (Wilkins 1608, A1r). Thus Gower is cast as the medium of the presentation (and Wilkins himself as a subsequent medium) rather than a fictional character within the play. To this the titling of Henry Gosson's 1609 quarto of Pericles sounds like something of a response, calling itself "THE LATE And much admired Play, Called Pericles, Prince of Tyre" (Shakespeare \& Wilkins 1609, A1r). This refers back to recent ("late") performance but also seems to insist that whereas the prose novella was a history of the play, here now is the play, unmediated: it is "THE . . . Play".

Butter had the previous year, 1608, published another Shakespeare play with a titlepage that refers back to a past performance and to the same company's ongoing performances. The title-page of the Pide Bull quarto of King Lear, printed for Butter by Nicholas Okes, indicated that the contents represented the chronicle history "As it was played before the Kings Maiestie at Whitehall vpon I S. Stephens night in Christmas Hollidayes. | By his Maiesties seruants playing vsually at the Gloabe | on the Banckeside" (Shakespeare 1608b, A2r). This phrasing was picked up by another stationer, Williams Jones, when publishing another King's men's play, the anonymous Mucedorus in 1610, as we shall shortly see. The title-page of the first printing of Mucedorus 12 years earlier refers to the contents as "Very delectable and full of mirth" and refers back, somewhat vaguely, to past performance by claiming that it is "Newly set foorth, as it hath bin I sundrie times plaide in the ho I norable Cittie of London". On the reverse of the titlepage is a doubling chart demonstrating that "Eight persons may easily play it" (Anonymous 1598). This is the same advertizing point--that fresh performances can originate from the printing--that we saw made on Tudor interludes' title-pages, although being placed here on the reverse of the title-page it would not have been visible in uncut copies of the book. If, however, extra copies of title-pages were printed for display on a bookseller's stall, as Alan B. Farmer and Zachary Lesser maintained (Farmer \& Lesser 2000,78 ), it could presumably have worked as an added inducement to buy. Like many books, the title-page of Mucedorus begins with a gathering of four leaves made from one printed sheet, and in such cases it is hard to see how such extra copies of the title-page could have been printed without also printing the first few hundred lines of the play, unless the forme were remade to use half-sheet imposition, which would still produce 2 unwanted pages from the start of the play. Perhaps some kind of quarter-sheet imposition was employed; with no surviving examples of advertizing title-pages we may never know how they were made.

Nor may we ever know whether the reverse of a title-page (which in complete books is often left blank) was also used for promotional purposes. In 1610 the stationer Williams Jones republished Mucedorus as "Amplified with new additions" reflecting how it had recently been performed at Whitehall "By his Highnes Seruantes vsually I playing at the Globe" (Anonymous 1610), which phrasing echoes the "playing vsually at the Gloabe" of the Shakespeare King Lear quarto of 1608. The doubling chart moved from the reverse of the title-page to the reverse of the prologue on the next leaf, and showed that two more actors were now needed for the new parts of "King Valencia" and "Anselmo", so that "Ten [formerly eight] persons may esily play it". In the meantime--that is, between the 1598 and 1610 printings of Mucedorus--appeared a play perhaps written by Thomas Heywood called The Fayre Mayde of the Exchange. It too has a doubling 
chart, printed underneath the phrasing familiar from Tudor interludes that indicates the intention that the book originate fresh performances: "Eleauen may easily acte this Comedie" (Anonymous [possibly Thomas Heywood] 1607, A2r). Although the title-page makes no reference to past performance, it describes the contents as "Very delectable, and full of mirth", the exact phrase used on the first edition of the period's only other play to be printed with a doubling chart, Mucedorus. It appears that something was happening in the second half of the first decade of the seventeenth century to make publishers think that it was worth describing their printed plays in terms that emphasized their capacity to originate fresh performances rather than reflect on past performances, although if we want to be sure that such developments were related to perceived promotional value we should confine ourselves to what is on the front of a title-page, not its reverse nor what appeared further inside the printed book.

\section{Xylographic 'THE'}

I mentioned that no play before Pericles is called a play on its title-page, which is true, but there had been a reference to plays, plural. The Conspiracie, and Tragedie of Charles Duke of Byron was the title of a printing of both parts of George Chapman's twoparter about the recent trial and execution of the Marshall of France. Its title-page claimed that the contents were "Acted lately in two playes, at the Black-friers" (Chapman $1608, A 1 r$ ), and these performances caused such grave offence that the all the playhouses were for a time closed and Henry Evans, impresario of the Children of the Blackfriars, surrendered his lease to Richard Burbage in August 1608 (Chambers 1923, 53-55). The wording of Thomas Thorpe's edition does not actually call the contents of his book the two plays--the Pericles quarto remains the first to do that since the Tudor interludes--but rather says that the book's contents were "acted . . . in" two plays. But there is another curious connection between the printing and ones we have been considering that seem to show a growing sense of the printed text as a part of, rather than a recapturing of, the performance matrix. The first word on the title-page of the 1608 printing of The Conspiracie, and Tragedie of Charles Duke of Byron is a xylographic (that is, woodcut) "THE" that Greg labelled "block 1", and in his reference list entry of Notabilia he recorded:

xylographs (lettering cut on wood): 'The' block 1 [203(a-c), 242(a)], block 2 [148(b), 243(a), 264(b), 308], block 2* [249(b, c), block 3 [256(a)]; 'Al Fooles' [219]; black-letter headings [412(c)]; and cf. woodcut in [414]

(Greg 1970b, 1642)

Greg died before completing this volume of his bibliography, and the index entry does not fully reflect what he knew and recorded in the preceding descriptions. For example, his descriptions of items 142e, 204a, 204c, 222, 274, 275 record use of the blocks but are not referred to in this index entry.

By his designations "block 1", "block 2", "block 2*", and "block 3" Greg appears to have meant that each is a particular design of woodcut letter, not particular pieces of wood reused in different printings. But in fact "block 1" is a single piece of wood used in different printings by different printers. In 1604 Valentine Simmes printed John Marston's The Malcontent for William Aspley with "block 1" on its title-page (Marston 1604, A1r) and to within fractions of a millimetre (attributable to paper expansion or contraction, and the vagaries of inking) the internal and external dimensions of the xylograph in British 
Library copy C.34.e.17 match those of the same block design on the title-page of Simmes's 1604 printing of Thomas Dekker and Thomas Middleton's The Honest Whore for John Hodgets (Dekker \& Middleton 1604, A1r), British Library copy at C.34.c.24. There are no obvious defects in the xylograph that one might use to determine with certainty that these two Simmes printings were made using the same piece of wood, but that is the obvious inference from the virtually identical dimensions.

No earlier play printing had such a xylographic "THE" on its title-page, but four others soon followed. In 1605 Thomas Creede printed The London Prodigall for Nathaniel Butter with the "block 1" design on its title-page (Anonymous 1605a, A1r) and in the British Library copy at C.34.I.3 it has precisely the dimensions of the one on the Simmes title-pages for The Malcontent and The Honest Whore. Moreover, in this printing there are a number of defects visible in the woodcut that enable us to determine that the next three times it appeared on play title-pages the same piece of wood was used: the top right serif of the $\mathrm{T}$ has chipped, the right side of the central horizontal bar of the $\mathrm{H}$ has taken ink (become filled where it should be hollow), the outer edge of curve in the top left corner of the $\mathrm{E}$ has worn away (taken no ink) where it comes closest to the top-right corner of the $\mathrm{H}$ before it, and the bottom edge of the bottom horizontal bar of the $\mathrm{E}$ has a small chip that the serif of the central bar points to. Those next three times this xylographic "THE" appears on a play title-page are: Chapman's The Gentleman Usher (Chapman 1606, A1r) printed in 1606 by Valentine Simmes for Thomas Thorpe, Heywood's? The Fayre Mayde of the Exchange (Anonymous [possibly Thomas Heywood] 1607, A1r) printed by persons unknown in 1607 for Henry Rocket, and Chapman's The Conspiracie, and Tragedie of Charles Duke of Byron (Chapman 1608, A1r) printed in 1608 by George Eld for Thomas Thorpe. The British Library copies of these (at C.12.g.4 (5), C.57.e.27 and C.30.e.2 respectively) show identical defects to the "THE" on the title-page of The London Prodigall, so these four plays' title-pages at least were printed using the same piece of wood. The two title-pages of 1604 by Simmes were made either with the same woodcut before it started to show wear, or from a woodcut that was virtually identical to the one subsequently used by Simmes, Creede, Rocket's unnamed printer, and Eld. The obvious inference, made by Akihiro Yamada and by Paul Edmondson, is that Simmes lent his decorative xylograph to men with whom he shared printing, as Creede and Eld were (Yamada 1994, 72-73; Edmondson 2001, 2, 22-23; Ferguson 1968, 88).

Whatever the explanation, putting a xylographic "THE" as the first word of a play titlepage became quite a popular thing to do, as seen in Middleton's The Phoenix (Middleton 1607, A1r) in 1607, Dekker and John Webster's The Famous History of Sir Thomas Wyat (Dekker \& Webster 1607, A1r) in 1607, Wilkins's The Miseries of Inforst Mariage (Wilkins 1611, A1r; Wilkins 1629, A1r) when reprinted in 1611 and 1629, the anonymous The Merry Devill of Edmonton (Anonymous 1612, A2r) when reprinted in 1612, Elizabeth Carew's The Tragedie of Mariam (Carew 1613, $\pi 2$ r) in 1613, and the anonymous The Famous Victories of Henry the Fifth (Anonymous 1617, A1r) when reprinted in 1617. The size and unusual design of the xylograph might, as Edmondson put it, "suggest that this play-text is the definitive article; the most longed for particular; the one and only" (Edmondson 2001, 22-23). On the other hand Simmes's use of the xylograph on half a dozen non-dramatic printings supports Ferguson's suggestion that it was simply a convenient means to express the printer's preference for the first line of a title-page being a large "THE" (Ferguson 1968, 79). Since over half the play titles in the period began with 'The', this decorative block was an economical way to embellish title-pages. 
The full list of publications in which Simmes used the xylograph was given by Ferguson (Ferguson 1968, 53) and includes the first edition of Michel de Montaigne's essays (Montaigne 1603) and the second edition of Laurence Twine's version of the Apollonius of Tyre (= Pericles) story (Apollonius of Tyre 1607) that Wilkins plagiarized heavily to make his prose novella The Painfull Adventures of Pericles Prince of Tyre. Indeed whenever his memory of the play he had written with Shakespeare failed him, Wilkins simply copied from Twine's book (Wells et al. 1987, 557-58). There is no reason to suppose that this particular connection with Wilkins via the xylograph is anything but coincidence.

Let us review the narrative so far. Around 1600-10, the front matter of printed plays began to suggest a new way of thinking about the relationship between performance and printed book. Instead of only harking back to past performances, title-pages began to refer to ongoing performances--"As it is now play[']d" (The Miseries of Inforst Marriage 1607 and The Travailes of the Three English Brothers 1607) and "playing vsually [or vsually playing] at the Glo[a]be" (King Lear 1608 and Mucedorus 1610)--and referred to their own ability to generate new performances by printing doubling charts (Mucedorus 1598 and The Fayre Mayde of the Exchange 1607). Around the same time the word "play" began to appear in the titles of textual versions of performances for the first time since the mid-sixteenth century, first in such misrepresentations as Nashe's Lenten Stuffe (1599), Vennard's England's Joy advertisement (1602), and R. S.'s The Jesuites Play at Lyons (1607), and then quite genuinely in the 1609 quarto of Pericles. At the same time, a xylographic "THE" began to appear on play title-pages, the first six examples being The Malcontent (1604) The Honest Whore (1604), The London Prodigall (1605), The Gentleman Usher (1606), The Fayre Mayde of the Exchange (1607) and The Conspiracie, and Tragedie of Byron (1607). As should now be apparent, much of this evidence can be linked via the King's men: The Miseries of Inforst Marriage, King Lear, Mucedorus, Pericles, and The London Prodigall were written for them, The Malcontent was a Blackfriars boys' play that they stole, and The Conspiracie, and Tragedie of Byron got the Blackfriars boys out of the Burbages's indoor playhouse, allowing the King's men to occupy it. These links may not be significant, for the King's men were the most successful troupe and there was a great deal happening around them.

\section{The Simpsons and the primordiality of text}

What has happening around 1600-10 that might have caused this shift in the purported relation between performance and print? We may never know for sure, but certain coincidences present themselves. The 1590s had been the heyday of the openair amphitheatres in London, with two companies (the Chamberlain's men and the Admiral's men) settled at two venues (the Theatre and the Rose) since 1594 and enjoying what Andrew Gurr characterized as settled practices made possible by their state-enforced duopoly of London playing (Gurr 1996, 78-104). Free of competition, these two companies developed enormous repertories, built a large customer base, earned vast quantities of money, and their star players acquired great personal fame. When James Burbage opened the Theatre in 1576 there had been competition of sorts from the semi-professional boys performing indoors at the Blackfriars and St Paul's, but the former ended in 1584 (Smith 1964, 130-52), and the latter in 1590 (Gair 1982, 112). Throughout the 1590s the professional adults had it all their own way, but at the turn of the century both boy companies started again (Smith 1964, 175-209; Gair 1982, 113- 
18). Perhaps renewed interest in indoor playing by non-professionals--the mode of consumption that the Tudor interludes were marketed for-- helped change readers' conception of the purpose of a printed play book.

Another possibility--an alternative or an addition to the one just offered--is a change regarding provincial touring. In a ground-breaking essay, Alan Somerset showed that far from being disconsolate meandering whilst barred from London during plague, provincial touring was highly organized, profitable, and attractive to the players (Somerset 1994). Indeed, the King's men toured more often and more widely under this name than they had as the Chamberlain's men, even when there was no prohibition on playing in London and even though they were pre-eminent there. Somerset speculates that their licence (the patent issued to the company) not only allowed them but also to a degree commanded them to play throughout the realm (Somerset 1994, 53). One of the wellknown effects of the arrival of travelling players is the renewal of interest in playing amongst those who are visited; Hamlet it typical in this regard. Travelling players might acquire their repertory by buying printed play texts, and in such a case the book would indeed precede rather than recapture a performance. For particular performances, the players or a patron (such as Hamlet) might insert additional material so that the performance exceeded the printed book on which it was based.

The matter of a performance exceeding print was of considerable importance to the playing company led by Robert and Christopher Simpson. Their patron Richard Cholmley was in London for the abortive Essex coup of 1601, for which he was imprisoned and fined; presumably it was to entertain such men that Essex's supporters paid the King's men for a performance of Richard 2 at the Globe on 7 February 1601. Charles Forker thought that this performance must have included the deposition scene that was not printed until Q4 (1608), else ". . the play could hardly have been thought to serve the rebels' political ends" (Shakespeare 2002, 10n2), whereas David M. Bergeron long ago maintained that the scene probably did not yet exist and in any case it evokes so much sympathy for Richard that the rebels would have preferred the play without it (Bergeron 1974, 34). Janet Clare pointed out that book censorship seems to have been no more severe than theatrical censorship, so the absence of the scene from the first three quartos strongly suggests that it was not performed else ". . . it would surely have been possible for the publisher, Matthew Lawe, to have obtained a fair copy prepared for stage use" (Clare 1990, 89). There is ample evidence that a written text might contain more than was performed, whether because the actors cut what they did not want to use--as Humphrey Moseley claimed in the preliminaries of the Beaumont and Fletcher Folio (Fletcher \& Beaumont 1647, A4r)--or, to look at essentially the same phenomenon another way, because the company had a "maximal" text authorized by the Master of the Revels but only ever played a subset of it, the "minimal" text suited to the particularies of occasion and cast (Gurr 1999).

The cutting of an allowed written text for performance is a practice that early modern theatre history can easily accommodate within its current set of working assumptions, but we have tended to draw a line regarding the writing of dramatic material solely for publication. Joseph Loewenstein argued that Ben Jonson is the central figure here, and that his carving out of an authorial identity for himself was "a groping forward toward later authorial property rights within a bourgeois cultural marketplace, but modelled on the ethos of the classical auctor and the economics of patronage" (Loewenstein 1985, 109). Jonson certainly wrote and rewrote for publication, but Lukas Erne's suggestion 
that Shakespeare too deliberately wrote material intended for the printed page not the theatre stage would, if accepted, upturn many of our assumptions (Erne 2002; Erne 2003). In Erne's explanation of the publication of Shakespeare's play is discernible a marked shift around the turn of the century (that is, coinciding with the shift we have been examining): the market for printed plays was glutted (Blayney 1997, 384-89) and there was more live and printed drama available once the boy companies restarted and their plays were printed (Erne 2002, 16). Broadening the appeal of printed plays--going beyond the simple recapture of open-air amphitheatre performance--might have been a marketing response to such pressure.

That a printed play contained no less than was performed was crucial to the defence mounted by the actors from the Simpsons company that were made to give an account of themselves at the trial of Sir John Yorke (Boddy 1976, 104-07). In Yorke's house on 2 February 1609 the company performed a play about Saint Christopher, which subject could offend no-one had not the players inserted a interlude in which a Catholic priest disputed with and overcame a Protestant minister, and had him carried away amid theatrical thunder-and-lightning by a devil. (That this sounds much like the scene from The Jesuites Play at Lyons described above, which also used "inuented Fyre-workes" (S $1607, \mathrm{~B} 1 \mathrm{v}$ ), is itself a lesson in how similar narrative descriptions can derive from performances that present wildly different religious meanings.) The witnesses from the playing company knew that the charge against Yorke centered on this interpolated scene, and Richard Simpson insisted that "That booke by which he and the other persons did act the said play ... was a prynted book, And they onlie acted the same according to the contents ... and not otherwise" (Boddy 1976, 106).

As well as the obvious perjury in this testimony--no authorized book about Saint Christopher could contain the scene described--we might suspect disingenuousness by Simpson: in all innocence, he seems to imply, we here in Yorkshire assumed that whatever was published in London must have been properly approved. Sisson even wondered if the company invented the book that they claimed to performed Saint Christopher from, "of which no trace appears to remain" (Sisson 1942, 142), but the other three printed playbooks cited by the players in their testimony are well-known to us: The Travailes of the Three English Brothers (Day, Rowley \& Wilkins 1607), called by them "The Three Shirleys" (Boddy 1976, 104), and "Perocles, prince of Tire, And the other was Kinge Lere" (Boddy 1976, 106). No doubt "Perocles" was Pericles (Shakespeare \& Wilkins 1609) and "Kinge Lere" was either the anonymous chronicle play (Anonymous 1605b) or Shakespeare's (Shakespeare 1608b).

If "Kinge Lere" was Shakespeare's play, then all three plays we know this company performed from printed texts were among the first whose title-page show the shift from a backward-looking relationship with performance ('as it hath been acted') to a presenttense phrasing on its way to becoming the Janus-face relation that included the possibility of the printed book originating fresh performances. The title-page of Day, Rowley, and Wilkins's The Travailes of the Three English Brothers (Day, Rowley \& Wilkins 1607, A1r) was joint-first to use the "As it is now play'd" phrasing, the title-page of Shakespeare's King Lear was first to inform the reader that the actors could be found "playing vsually at the Gloabe" (Shakespeare 1608b, A2r). Before Pericles no-one had thought to put "THE . . . Play" on a printed drama's title-page (Shakespeare \& Wilkins $1609, \mathrm{~A} 1 \mathrm{r}$ ) since the Tudor interlude printings that foregrounded their capacity to originate performance. Two people recur in this pattern: Wilkins as writer of two of the 
three plays (and of The Miseries of Inforst Mariage, the other joint-first to use "As it is now played" on its title-page), and Butter as publisher of King Lear and of Wilkins's prose novella version of the play Pericles called The Painfull Adventures of Pericles Prince of Tyre (Wilkins 1608).

In all likelihood there is an element of random coincidence at work here, and that if Wilkins and Butter were indeed responsible for these innovative phrasings, they were not conscious of the novelty. In their everday work of writing and publishing I do not suppose that these men thought terribly hard about the significance of present-tense and future-tense locutions, for they worked to produce and disseminate performances and books for money. But it would, I think, be stretching coincidence to say that the playing company in Yorkshire that bought these books and performed what was in them were unaffected by the new phrasing. It would be a remarkable coincidence indeed if the three plays that betray the new forward thinking were by chance the ones that the Simpsons company happened upon. It seems more likely that the actors picked up what was implied by this shift in how title-pages characterized their relationship to performance, and when challenged they excused themselves with the assertion that the books, not the players, were the authors of their performances.

\section{Works Cited}

Anonymous [possibly Thomas Heywood]. 1607. The Fayre Mayde of the Exchange. STC 13317 BEPD 242a. London. [Valentine Simmes for] Henry Rocket.

Anonymous. 1522. Here Begynneth a Propre Newe Interlude of the Worlde and the Chylde, Otherwise Called [Mundus and Infans]. STC 25982 BEPD 5. London. Wynkun de Worde.

Anonymous. 1560?. [Little Gest of Robin Hood] A Mery Geste of Robyn Hoode and of His Lyfe, Wyth a Newe Playe for to be Plaied in May-games. STC 13691 BEPD 32a. London. William Copland.

Anonymous. 1598. A Most Pleasant Comedie of Mucedorus. Newly Set Foorth. STC 18230 BEPD 151a. London. for William Jones.

Anonymous. 1605a. The London Prodigall. As it Was Plaide By the Kings Majesties Servants. By W. Shakespeare. STC 22333 BEPD 222a. London. T[homas] C[reede] for Nathaniel Butter.

Anonymous. 1605b. The True Chronicle History of King Leir, and His Three Daughters. STC 15343 BEPD 213. London. Simon Stafford for John Wright.

Anonymous. 1605c. Two Most Unnatural and Bloodie Murthers: the One By Maister Caverly, a Yorkshire Gentleman. The Other, By Mistris Browne. STC 18288. London. Valentine S[immes] for Nathaniel Butter.

Anonymous. 1610. A Most Pleasant Comedie of Mucedorus. Amplified with New Additions. STC 18232 BEPD 151c. London. [William White] for William Jones. 
Anonymous. 1612. The Merry Devill of Edmonton. STC 7494 BEPD 264b. London.

Thomas Creede for Arthur Johnson.

Anonymous. 1617. The Famous Victories of Henry the Fifth. STC 13073 BEPD $148 b 1$. London. Bernard Alsop.

Apollonius of Tyre. 1607. The Patterne of Paineful Aduentures: Containing the Most Excellent, Pleasant, and Variable Historie of the Strange Accidents That Befell Vnto Prince Apollonius ... Gathered Into English By T. [Sic] Twine. STC 710. London.

Valentine Simmes.

Arber, Edward, ed. 1875. A Transcript of the Registers of the Company of Stationers of London 1554-1640. Vol. 2: Text. Entries of Books to 25 June 1595; Entries of

Apprentices and Freemen, Calls on the Livery, and Fines to 2 July 1605. 5 vols. London. Privately printed.

Arber, Edward, ed. 1876. A Transcript of the Registers of the Company of Stationers of London 1554-1640 AD. Vol. 3: Text. Entries of Books to 11 July 1620; Entries of Freemen to 31 December 1640; Succession of Master Printers in London 1586-1636. 5 vols. London. Privately Printed.

Arber, Edward, ed. 1877. A Transcript of the Registers of the Company of Stationers of London 1554-1640 AD. Vol. 4: Text: Entries of Books to 3 November 1640; Calls on the Livery and Promotions to the Assistance to 31 December 1640. London. Privately printed.

Bell, Thomas. 1604. The Downefall of Poperie: Proposed By Way of a New Challenge to English Jesuits. STC 1818.5 (formerly 1817). London. for Nathaniel Butter.

Bergeron, David M. 1974. "The Deposition Scene in Richard II." Renaissance Papers. 31-37.

Blayney, Peter W. M. 1997. "The Publication of Playbooks." A New History of Early English Drama. Edited by John D. Cox and David Scott Kastan. New York. Columbia University Press. 383-422.

Boddy, G. W. 1976. "Players of Interludes in North Yorkshire in the Early Seventeenth Century." North Yorkshire Country Records Office Journal. 3. 95-130.

Carew, Elizabeth. 1613. The Tragedie of Mariam, the Faire Queene of Jewry. Written By That Noble Ladie, E. C.. STC 4613 BEPD 308A1, A2. London. Thomas Creede for Richard Hawkins.

Chambers, E. K. 1923. The Elizabethan Stage. Vol. 2. 4 vols. Oxford. Clarendon.

Chapman, George. 1606. The Gentleman Usher. STC 4978 BEPD 226. London. V[alentine] S[immes] for Thomas Thorpe. 
Chapman, George. 1608. The Conspiracie, and Tragedie of Charles Duke of Byron, Marshall of France. Acted Lately in Two Playes. STC 4968 BEPD 274a, 275a. London. G[eorge] Eld for Thomas Thorppe, sold [by Laurence Lisle].

Clare, Janet. 1990. "The Censorship of the Deposition Scene in Richard II." Review of English Studies. 44. 89-94.

Day, John, William Rowley and George Wilkins. 1607. The Travailes of the Three English Brothers: Sir Thomas, Sir Anthony, and Master Robert Shirley. STC 6417 BEPD 248A1, A2. London. [George Eld] for John Wright.

Dekker, Thomas and John Webster. 1607. The Famous History of Sir Thomas Wyat. With the Coronation of Queen Mary. Written By Thomas Dickers, and John Webster. STC 6537 BEPD 256a. London. E[dward] A[llde] for Thomas Archer.

Dekker, Thomas and Thomas Middleton. 1604. The Honest Whore, With, the Humours of the Patient Man, and the Longing Wife. STC 6501 BEPD 204a. London. V[alentine] S[immes] for John Hodgets.

Edmondson, Paul. 2001. A Critical Edition of The London Prodigal. Unpublished PhD thesis. Birmingham. University of Birmingham.

Edwards, Richard. 1571. Damon and Pithias. STC 7514 BEPD 58a. London. [William Williamson for] Richard Jones.

Edwards, Richard. 1582. Damon and Pithias. STC 7515 BEPD 58b. London. Richard Jones.

Erne, Lukas. 2002. "Shakespeare and the Publication of His Plays." Shakespeare Quarterly. 53. 1-20.

Erne, Lukas. 2003. Shakespeare as Literary Dramatist. Cambridge. Cambridge University Press.

Farmer, Alan B. and Zachary Lesser. 2000. "Vile Arts: The Marketing of English Printed Drama, 1512-1660." Research Opportunities in Renaissance Drama. 39. 77-165.

Ferguson, W. Craig. 1968. Valentine Simmes: Printer to Drayton, Shakespeare, Chapman, Greene, Dekker, Middleton, Daniel, Jonson, Marlowe, Marston, Heywood, and Other Elizabethans. Charlottesville VA. Bibliographical Society of the University of Virginia.

Fletcher, John and Francis Beaumont. 1647. Comedies and Tragedies. Wing B1581. London. For Humphrey Robinson, and Humphrey Mosely.

Gair, Reavley. 1982. The Children of Paul's: The Story of a Theatre Company, 15531608. Cambridge. Cambridge University Press. 
Greg, W. W. 1970a. A Bibliography of the English Printed Drama to the Restoration. Vol. 1: Stationers' Records; Plays to 1616: Nos. 1-349. 4 vols. London. The Bibliographical Society.

Greg, W. W. 1970b. A Bibliography of the English Printed Drama to the Restoration. Vol. 3 Collections, Appendix, Reference Lists. 4 vols. London. The Bibliographical Society.

Greg, W. W. and E. Boswell, eds. 1930. Records of the Court of the Stationers' Company 1576 to 1602 from Register B. London. The Bibliographical Society.

Gurr, Andrew. 1996. The Shakespearian Playing Companies. Oxford. Clarendon Press.

Gurr, Andrew. 1999. "Maximal and Minimal Texts: Shakespeare V. the Globe." Shakespeare Survey. 52. 68-87.

Herbert, William. 1786. Typographical Antiquities, or an Historical Account of the Origin and Progress of Printing in Great Britain and Ireland: Containing Memoirs of Our Ancient Printers, and a Register of Book Printed By Them, from the Year 1471 to the Year 1600, Begun By the Late Joseph Ames. Vol. 2. 3 vols. London. Privately printed for the editor.

Heywood, John. 1533. The Play of the Wether. STC 13305 BEPD 15a. London. William Rastell.

Heywood, John. 1534. A Play of Loue. STC 13303 BEPD 16a. London. W[illiam] Rastell. Heywood, John. 1544?a. The Play of the Wether. STC 13305.5 BEPD 15b. London. [William Middleton].

Heywood, John. 1544?b. The Playe Called the Foure PP. STC 13300 BEPD 21a. London. Wyllyam Myddylton.

Heywood, John. 1560?. The Playe Called the Foure PP. STC 13301 BEPD 21b. London. Wyllyam Copland.

Heywood, John. 1569. The Playe Called the Foure PP. STC 13302 BEPD 21c. London. John Allde.

Heywood, John. c.1560. The Play of the Wether. STC 13306 BEPD 15c. London. [John Tisdale for] Anthony Kitson.

Heywood, John. c.1573. The Play of the Wether. STC 13307 BEPD 15d. London. John (=Sampson) Awdely.

Holland, Peter. 2004. "'Theatre Without Drama: Reading REED'." From Script to Stage in Early Modern England. Edited by Peter Hollard and Stephen Orgel. Redefining British Theatre History. 1. New York. Palgrave Macmillan. 43-67.

Jackson, William A., ed. 1957. Records of the Court of the Stationers' Company 1602 to 1640. London. The Bibliographical Society. 
Loewenstein, Joseph. 1985. "The Script in the Marketplace." Representations. 12. 10114.

Marlowe, Christopher and Thomas Nashe. 1594. The Tragedie of Dido Queene of Carthage. STC 17441 BEPD 128. London. The widow Orwin for Thomas Woodcocke.

Marston, John. 1604. The Malcontent. STC 17479 BEPD 203c. London. V[alentine] S[immes] for William Aspley.

McKerrow, R. B. 1916. "Booksellers, Printers, and the Stationers' Trade." Shakespeare's England. 2. Edited by Sidney Lee and C. T. Onions. Oxford. Clarendon Press. 212-39.

McKerrow, Ronald B., ed. 1910. A Dictionary of Printers and Booksellers in England, Scotland and Ireland, and of Foreign Printers of English Books 1557-1640. London. The Bibliographical Society.

Medwall, Henry. 1512-16. Here is Co[n]teyned a Godely Interlude of Fulgens Cenatoure of Rome. STC 17778 BEPD 1, 2. London. John Rastell.

Middleton, Thomas. 1607. The Phoenix, as it Hath Been Acted. STC 17892 BEPD 243a. London. E[dward] A[llde] for A[rthur] J[ohnson].

Montaigne, Michel de. 1603. The Essays or Morall, Politike and Millitarie Discourses ... Done Into English By. . . John Florio. STC 18041. London. Valentine Simmes for Edward Blount.

Nash, Thomas. 1599. Nashes Lenten Stuffe, Containing, the Description of Great Yarmouth. With a New Playe of the Praise of the Red Herring. STC 18370. London. [Thomas Judson and Valentine Simmes] for Nicholas L[ing (Lyng)] and C[uthbert] $\mathrm{B}$ [urby].

Pollard, A. W. and G. R. Redgrave. 1991. A Short-title Catalogue of Books Printed in England, Scotland, \%26 Ireland and of English Books Printed Abroad 1475-1640. Vol. 3: A Printers' and Publishers' Index, Other Indexes and Appendices, Cumulative Addenda and Corrigenda By Katharine F. Pantzer, with a Chronological Index By Philip R. Rider. 3 vols. London. The Bibliographical Society.

Rastell, John. 1520?. A New luterlude [Sic] and a Merry of the Nature of the liij Elements. STC 20722 BEPD 6. London. [John Rastell].

S, R. 1607. The Jesuites Play at Lyons in France, as it Was There Presented. STC 21513.5. London. [William Jaggard and John Windet] for Nathaniel Butter.

Shakespeare, William and George Wilkins. 1609. [Pericles] The Late, and Much Admired Play Called Pericles, Prince of Tyre. STC 22334 BEPD 284a (Q1). London. [William White] for Henry Gosson.

Shakespeare, William. 1597. [Richard 2] The Tragedie of King Richard the Second. STC 22307 (Q1) BEPD 141a. London. Valentine Simmes for Andrew Wise. 
Shakespeare, William. 1608a. A Yorkshire Tragedy. Not so New as Lamentable and True ... Written By W. Shakspeare. STC 22340 BEPD 272a. London. R[ichard] $\mathrm{B}$ [raddock] for Thomas Pavier.

Shakespeare, William. 1608b. [King Lear] M. William Shak-speare: His True Chronicle Historie of the Life and Death of King Lear and His Three Daughters. STC 22292 BEPD 265a (Q1). London. [Nicholas Okes] for Nathaniel Butter.

Shakespeare, William. 1609a. [Troilus and Cressida] The Famous Historie of Troylus and Cresseid. STC 22332 BEPD 279a2 (Qb). London. George Eld for Richard Bonian and Henry Walley.

Shakespeare, William. 1609b. [Troilus and Cressida] The Historie of Troylus and Cresseida. As it Was Acted, Etcetera. STC 22331 BEPD 279a1 (Qa). London. George Eld for Richard Bonian and Henry Walley.

Shakespeare, William. 2002. King Richard II. Ed. Charles R. Forker. The Arden Shakespeare. London. Thomson Learning.

Sisson, C. J. 1942. "Shakespeare Quartos as Prompt-copies." Review of English Studies. 18. 129-43.

Smith, George, Leslie Stephen and Sidney Lee, eds. 1937-38. The Dictionary of National Biography: From the Earliest Times to 1900. Vol. 3: Brown-Chaloner. 22 vols. Oxford. Oxford University Press.

Smith, Irwin. 1964. Shakespeare's Blackfriars Playhouse: Its History and Its Design. New York. New York University Press.

Somerset, Alan. 1994. "'How Chances it They Travel':? Provincial Touring, Playing Places, and the King's Men." Shakespeare Survey. 47. 45-60.

Stern, Tiffany. forthcoming. "'On Each Wall / And Corner Poast': Playbills, Title-pages, and Advertising in Early Modern London." English Literary Renaissance. TBA. TBA.

Taylor, Gary. 1982. "Troilus and Cressida: Bibliography, Performance, and Interpretation." Shakespeare Studies. 15. 99-136.

Vennard, Richard. 1602. The Plot of the Play, Called Englands Joy. To be Playd at the Swan This 6 of November 1602. STC 24636.7. London. [John Windet].

Wager, Lewis. 1566. Life and Repentance of Marie Magdalene. STC 24932 BEPD 47A. London. John Charlewood.

Wells, Stanley, Gary Taylor, John Jowett and William Montgomery. 1987. William Shakespeare: A Textual Companion. Oxford. Oxford University Press.

Wilkins, George. 1607. The Miseries of Inforst Mariage. As it is Now Playd. STC 25635 BEPD 249a. London. [William Jaggard] for George Vincent. 
Wilkins, George. 1608. The Painfull Adventures of Pericles Prince of Tyre. Being the True History of the Play of Pericles, as Presented By J. Gower. STC 25638.5 [formerly 19628]. London. T[homas] P[urfoot] for Nat[haniel] Butter.

Wilkins, George. 1611. The Miseries of Inforst Mariage. STC 25636 BEPD 249b. London. [William White] for George Vincent.

Wilkins, George. 1629. The Miseries of Inforst Mariage. STC 25637 BEPD 249c. London. Aug[ustine] Mathewes for Richard Thrale.

Woodes, Nathaniel. 1581. An Excellent New Commedie, Intituled: The Conflict of Conscience. Contayninge, the Most Lamentable Hystorie, of the Desperation of Frauncis Spera. STC 25966 BEPD 78A1. London. Richard Bradock.

Yamada, Akihiro. 1994. Thomas Creede: Printer to Shakespeare and His Contemporaries. Tokyo. Meisei University Press. 